\title{
Exploration and Research on the Application of Action Learning in the Teaching of Automobile Structure
}

\author{
Xu Yang \\ Huanghe Science and Technology College \\ Zhengzhou, China 450063 \\ Dongsheng Wang \\ Henan Boda microwave equipment Co., Ltd, \\ Zhengzhou, China 450003
}

\author{
Shaoju Hao \\ Henan Radio and Television University \\ Zhengzhou, China 450001 \\ Hao Yang \\ Students of Mechanical Major Undergraduate \\ Zhengzhou, China 450063
}

\begin{abstract}
The action learning method is a new teaching mode which takes the students as the center, meets the needs of the students, and complies with the development of the times. It breaks through the limitation of the traditional teaching mode, and can effectively improve the teaching quality and teaching effect. Automobile structure is a required course for automobile application. In traditional teaching methods, students often only focus on the knowledge of memory, lack of independent thinking and initiative, to explore suitable for the "automobile structure" course teaching strategy is a priority. The introduction of action learning into the teaching reform of automobile construction course can improve students' learning interest, stimulate students' initiative and cultivate students' ability to solve problems independently.
\end{abstract}

Keywords-action learning method; automobile application specialty; teaching method; three person group activity

\section{INTRODUCTION}

Automobile construction course is the main course of automobile application. It is not only an important foundation for the follow-up courses of study, but also the students' exposure to the profession. Through the automobile structure course of study, students can grasp the basic knowledge of vehicle structure, knowledge of the basic assembly of the role, structure characteristics, working principle and so on, understand modern automobile new structure, new technology. The traditional teaching methods of automobile construction take the teacher as the center, and are limited to the teacher's classroom instruction. Students tend to focus only on the knowledge of memory, lack of self thinking space and their own subjective initiative. This kind of teaching mode has hindered the development of students' subjectivity, and not conducive to training students' ability to cooperate. In order to stimulate students' interest in learning, improve students' application ability, so that students from the "want me to learn" to "I want to learn", the teaching method must be improved. Action learning as inheritance and Transcendence of the traditional teaching method is an effective learning method in accordance with this trend. Taking the teaching practice of "automobile structure" as an example, this paper discusses the improvement and optimization of the teaching and learning quality of the course of action learning, which is based on the teaching practice of the core course of automobile application and maintenance specialty in Huanghe Science and Technology College.

\section{OVER VIEW OF ACTION LEARNING}

\section{A. Definition of Action Learning}

The action learning method was proposed by Professor Revens Reg in 1965. In 1940, he went to Belgium to organize and manage the training courses for senior management, which was the first to introduce this method into the scientific academic field of management development. Action learning, also known as "learning by doing", is to practice to rely on, to learn team as a unit, with real case as the object, to the role of the team members play as a means, to solve problems and achieve the development of individual and group as the goal is learning knowledge, sharing experiences and creative study and solve problems and practical action to one of the four methods.

\section{B. Application and Development of Action Learning}

On the meaning of action learning, its founder professor Revans Reg uses the formula " $\mathrm{L}=\mathrm{P}+\mathrm{Q}$ " to express. Among them, $\mathrm{P}$ (Knowledge Programmed) said that the teaching of structured knowledge". Q (Insight Questioning) is refers to the "deep reflection on the question" - based learning. Action learning is a kind of teaching mode which combines the knowledge teaching and the reflection question. In the world top 500 enterprises have been widely used and promoted, more and more enterprises in the world to action learning as a more effective, more powerful management tools, training methods. Pedler Mike expanded the formula as to: $\mathrm{L}=\mathrm{Q} 1+\mathrm{P}+\mathrm{Q} 2$. He pointed out that the most effective learning 
should be based on the relevant questions, confusion or the opportunity to ask questions to start (Q1), through the guidance or teaching method of learning $(\mathrm{P})$, will trigger a re definition of the problem (Q2). Mcgill Ian and Betty Liz pointed out: "action learning is a process of continuous reflection and learning with the support of colleagues in order to accomplish the intended work. Through the continuous improvement and development of scholars, at present, the formula of action learning has been further modified and expanded to: $\mathrm{AL}=\mathrm{P}+\mathrm{Q}+\mathrm{R}+\mathrm{I}$. Among them, $\mathrm{AL}$ (Learning Action) refers to the action learning, $\mathrm{P}$ (Knowledge Programmed) refers to the structured knowledge, Q (Questions) that is proposed to be rich insight into the problem, R (Reflection) that is, I (Implementation), that is, the implementation of (). That is, action learning = structured knowledge + questioning + reflection + execution.

Action learning from university personnel training angle is defined as: in teaching, aiming at the actual problems existing in a society, learners through team work and experience sharing and continuous reflections, creative problem solving, so as to learn from each other, mutually promote and continuously improve the process. Through the way of action learning, team members by the joint efforts of the group, in the process of exploring and solving problems, to be able to obtain continuous growth and development.

\section{The Teaching Steps of Action Learning}

There are four parts of the action learning method, namely, the problem; the formation of action learning group; to carry out learning and solving problems; class discussion and report. Specifically, action is based on the experience and support of the team members to rely on the problem as the center, to carry out creative thinking to carry out teaching activities.

\section{Rational Choice Problem}

In the action learning method, the problem is not the teacher designated, but by the team members to discuss the choice. Because of their own problems, students can participate more actively in the process of learning. At this stage, teachers must guide students to follow the teaching outline of automobile structure, and the design of teaching problems based on the professional skills. With the education of the auto parts organization as an example, the problem can be developed around three levels: the first level is the basic knowledge, the students must master. The second level is a certain depth and difficulty of the problem, it is possible to explore through the action learning method to grasp. For example, the working principle of the variable timing mechanism of auto parts, the third level is the comprehensive analysis ability training, need to analyze the problem with a certain typical and strong comprehensive, comprehensive requirements for students. For example, the reason of the lack of cylinder compression pressure analysis, the need for students to have certain knowledge of reserves to be analyzed.

\section{E. Building an Action Learning Group}

Action learning group composed of 3-14, supporters, statements, questions and listeners role play by each member of group. Each member needs to understand their role responsibilities, such as statement to his group presentation and to seek feedback from other members and make improvement of the next step work "action points" in the group's help; supporters, as a listener, by listening to, response and the consultation asked, help the statements to explore issues and formed new points; promoter by skill to control the team, the team members to interact effectively.

\section{F. Team to Carry out Learning; Teachers Do a Good Job of Supervision}

Each group organizes team members to discuss by their choice the task, and put forward their preliminary views, to find the best way to solve the task. During this period, the team will need to collect the relevant information, complete preliminary cognition, form a preliminary view, and then carry out the task in the case of teachers to participate in the discussion. The fishbone diagram method, brainstorming, six thinking hat method, group listing method thinking tools presented their own views, to find the best way to solve the problem are discussed, and finally the formation of solutions. Teachers to discuss the principle of non intervention, mainly from the role of guiding the task of the group. The process of learning is through dialogue, discussion and other means of communication process, which is the process of questioning and reflection of students.

\section{G. Post Evaluation}

Late stage evaluation is mainly to complete three tasks: one is the student the implementation process of the task force were summarized and discussed, self analysis of the achievements and shortcomings, showing self grow up feeling; second between each group to the other team's task to complete, for comment and discussion, learning the advantages of other groups, found its own lack of; teachers on each team task review and summary for the implementation of process control are given. Teachers in guiding students to complete the above tasks, to the study of this action to summarize, evaluate the results of this action learning projects and achievements. Based on the formulation of incentive methods to motivate the team and members of the performance of this learning action. Post evaluation is the solution of this action learning to fine, process, standardization, and to share the process of other groups.

\section{PRACTICAL APPLICATION OF ACTION LEARNING IN THE TEACHING OF “Automobile STRUCTURE”}

Three person group activities are the specific teaching methods for action learning. The basic idea is to set up a group of 3 students for a group discussion. Each person has a different role to play, so that students can take the initiative to participate in the discussion, can take the initiative to play. On the basis of the three groups of members of the exchange, to achieve the purpose of group communication. Combining 
the three and the 9 group comprehensive discussion of the results, the results of the whole class to share, the teacher at the end of the results. The way of activity reflects the meaning of action learning. Take 100 minutes of classroom as an example, the specific steps are shown in "Table I".

TABLE I. 100 Minutes of ClassRoom TEACHING AND Distribution OPERATION STEPS

\begin{tabular}{|c|c|c|c|}
\hline NO. & Teaching content & time & function \\
\hline 1 & On the need to discuss the support materials to explain, this course to discuss topics & 10-15Min & $\begin{array}{l}\text { Knowledge reserve before the } \\
\text { discussion }\end{array}$ \\
\hline 2 & $\begin{array}{l}\text { Set up three groups, assign roles, and decorate communication tasks or learning } \\
\text { tasks. }\end{array}$ & 3-5 Min & $\begin{array}{l}\text { The presenter, facilitator, } \\
\text { observer three role }\end{array}$ \\
\hline 3 & Exchange roles within the group, mutual exchange & 9 Min & $\begin{array}{l}\text { Everyone has different tasks and } \\
\text { role experience }\end{array}$ \\
\hline 4 & Re divided into three groups, to exchange & $8 \mathrm{Min}$ & Interactive learning experience \\
\hline 5 & Each 33 people into a group of 9 people, 9 groups of communication & 10 Min & Communication between groups \\
\hline 6 & The class share the results of the discussion & 20--30 Min & $\begin{array}{l}\text { The results of the study group } \\
\text { show }\end{array}$ \\
\hline 7 & Teacher summary & 10 Min & Evaluation and motivation \\
\hline
\end{tabular}

For example explain the piston ring structure and maintenance "section, the piston ring is adapt to the complex work environment, need in the cross section of the surface, coating for technical improvement, which resulted in practical work for piston ring installing direction and position have many regulations and operation skill. While the content of the textbooks is messy, students are not easy to sum up and memory. The trio of teaching mode. At first, the teacher explained the working environment of the piston ring, supporting theories and knowledge need secondary seal principle and pump oil phenomenon is discussed in the next step, put forward "piston ring the correct installation methods have what note". Then in accordance with the above steps and the time distribution of the student organization of group discussion, exchange discussion and large group, during which teachers visited the classroom, urge the group behind the study process, the students answer discussion questions generated in the process of. In the final sharing can be found that students not only from the textbooks to find the correct installation of the piston ring all the answers, but also on the answer to the use of the knowledge learned to explain the principle of. Have the students put forward no textbooks of new ideas, new old piston ring mixed harm, coke deposition on piston ring life influence, the classroom atmosphere active, all students arouse the study enthusiasm, in order to achieve the teaching goal.

About the automobile structure teaching using action learning effect, by student feedback evaluation system; teachers of students usually curriculum participation degree, operation and daily test results of the assessment; supervision lectures and test analysis of educational organizations in the, comprehensive analysis as shown in "Table II".

TABLE II. COMPREHENSIVE COMPARISON TABLE OF ACTION LEARNING AND TRADITIONAL TEACHING METHOD

\begin{tabular}{|c|c|c|c|}
\hline $\begin{array}{l}\text { assessment } \\
\text { element }\end{array}$ & Content evaluation & $\begin{array}{l}\text { Evaluation of action } \\
\text { learning }\end{array}$ & $\begin{array}{l}\text { Evaluation of } \\
\text { traditional teaching } \\
\text { method }\end{array}$ \\
\hline \multirow{8}{*}{$\begin{array}{l}\text { Students } \\
\text { learning style }\end{array}$} & $\begin{array}{l}\text { 1.Emotional attitude: a strong interest, learn easily, active participation, } \\
\text { autonomy, student music learning. }\end{array}$ & good & normal \\
\hline & $\begin{array}{l}\text { 2.Student participation: participate in the occurrence, development and } \\
\text { formation of knowledge. }\end{array}$ & good & normal \\
\hline & 3.Cooperation level: active learning atmosphere, warm discussion. & good & normal \\
\hline & 4.Ability to express: Express smooth, voice loud, clear and logical. & good & normal \\
\hline & $\begin{array}{l}\text { 5.Thinking quality: focus, quick thinking, memory, observation, imagination, } \\
\text { self reflective ability to get effective training. }\end{array}$ & good & normal \\
\hline & $\begin{array}{l}\text { 6. Learning methods: through the observation, the exchange of active access } \\
\text { to knowledge, the formation of skills. }\end{array}$ & good & normal \\
\hline & $\begin{array}{l}\text { 7.Learning ability: preview in place, independent thinking, active exploration, } \\
\text { have good listening and discussion, questioning, writing, reading habits. }\end{array}$ & good & normal \\
\hline & $\begin{array}{l}\text { 8.Innovative ability: good at evaluation, dare to express different views, } \\
\text { questioned novel, not for the pursuit of the courage to compete, be good at } \\
\text { study, overcome difficulties and achieve success. }\end{array}$ & good & normal \\
\hline $\begin{array}{c}\text { teaching } \\
\text { effectiveness }\end{array}$ & $\begin{array}{l}\text { 9.Detection of feedback effect, training to achieve the desired goals, achieves } \\
\text { development goals; achieve the goal of teaching the proportion of students. }\end{array}$ & $90 \%$ & $70 \%$ \\
\hline
\end{tabular}

\section{CONCLUSION}

Action learning make full use of the characteristics of the existing classroom space and promote the interaction and communication between students, for teachers to promote students parallel interaction and communication provides a useful form of classroom organization, conform to the theoretical knowledge of the nature of the acquisition. In the actual classroom teaching, taking the students as the main body and the center, the enthusiasm and interest of the students to learn the theory of automobile structure is improved, and the trend of the reform of modern curriculum and teaching theory. Action learning from an emphasis on "learning to apply", emphasize knowledge conversion 
capability, knowledge conversion for practice, in line with the basic spirit of higher education. The introduction of action learning into the classroom teaching of automobile structure is also a further guarantee of teaching quality from the teaching strategy.

Action learning in teaching practice exploration and utilization is a system engineering, need to relevant management departments in Colleges and universities attach great importance to and the main force of full participation, need to have experience of learning guidance of learning methods and the process of the profound understanding and grasp of the needs organizers and participants of the in-depth study of the learning process and continue to sum up. Effective value of action learning also need more colleges and universities in the teaching practice of verification and popularization of automobile application, try to explore to the teaching reform of colleges and universities, the positioning of the future the goal of personnel training, personnel training mode optimization plays a direct role in promoting.

\section{ACKNOWLEDGMENT}

This work is supported by the national college students practice base, Henan Province ordinary university undergraduate engineering education personnel training mode reform pilot, Project of "professional comprehensive reform" in Colleges and Universities, specialty of Henan province, Henan provincial key disciplines and the Huanghe S\&T teaching reform research and other projects funded project.

\section{REFERENCES}

[1] ZH.T. Zhang, D. Li. Action learning method is worth promoting the learning method of Education and modernization.2005 (3).

[2] Mcgill Liz, Betty Ian. Chinese senior personnel management training center. Action learning method. Beijing: Huaxia publishing house. 2002:8.

[3] Y. Wang. The action learning concept to promote the construction of learning organization in.2011. Gui Hai Review(9).

[4] X.Y. Chen. Action learning: a new breakthrough of traditional teaching mode. Journal of Changchun Institute of Technology: Social Science Edition.2014 (2).

[5] B.ZH. Han , D. Wang, Y. X. Zhang. Trial and Reform in the Manufacturing Technology Foundation Course Based on the Ability Training. Journal of Taiyuan University of technology. Vol. 29,pp.8688, 2011. 